\title{
Determinant of Agroforestry Practices among Small Holder Farmers in Oyo State Nigeria
}

\author{
*OBADIMU, OO; OKE, OS; ASUNLEGAN, OA; ALAJE, MA; OJO, D; \\ OLANREWAJU, CM
}

Forestry Research Institute of Nigeria (FRIN) Ibadan Oyo State Nigeria

*Corresponding Author: Email: obadolusola@gmail.com

\begin{abstract}
The multiplicity of agroforestry practices demand the choice of appropriate methods that will give the rural farmers an excellent result. Thus, this study analysed the factors determining the choice of agroforestry practices among small holder farmers in Oyo State, Nigeria. Primary data was obtained using multi-stage sampling technique. Structured questionnaire was administered to 250 selected small holder farmers to elicit relevant information and 211 was retrieved and used for this study. The findings revealed that most $55 \%$ of the farmers chose agrisilvicutural system while $33.2 \%$ and $11.8 \%$ of the farmers chose agrosilvopastoral and silvopastoral systems respectively. Most of the farmers were males $89.1 \%$, with average age of 47 years indicating they were relatively young with basic formal education. The average farm size of 3.34ha indicated that the study covered small holder farmers. The multinomial logit result showed that factors such as educational level, meeting attendance, type of labour used, household assets significantly determined the choice of agroforestry practices adopted by the farmers. The study therefore recommends the implementation of policies that promote more enlightenment on the benefits of agroforestry to both the educated and non-educated farmers to facilitate quick adoption, provision of incentives to farmers that attend meetings regularly and making available improved agroforestry methods and practices to enhance wider suitability of agroforestry practices.
\end{abstract}

\section{DOI: https://dx.doi.org/10.4314/jasem.v24i12.16}

Copyright: Copyright (C) 2020 Obadimu et al. This is an open access article distributed under the Creative Commons Attribution License (CCL), which permits unrestricted use, distribution, and reproduction in any medium, provided the original work is properly cited.

Dates: Received: 01 October 2020; Revised: 23 November 2020; Accepted: 16 December 2020

Keywords: Agroforestry, Agrosilvopastoral, Agrisilviculture, Silvopastoral

Regardless of its significance, the natural tropical high forest has kept on reducing quickly in the African mainland, subsequently endangering the sustainability of sustainable forest management (Udofia, 2005) which has been found to be essential because of its important impact on biodiversity and significance in keeping up global ecological functions. The management of forest resources incorporating agricultural practices is called agroforestry. FAO, (2015) defined it as a collective name for land-use systems and technologies where woody perennials (trees, shrubs, palms, bamboos, etc.) are deliberately used on the same land-management units as agricultural crops and/or animals, in some form of spatial arrangement or temporal sequence. This depicts that both ecological and economical interactions between the different components make up the agroforestry systems. It is diverse in nature, ecologically based and made up of natural resources. According to Alao and Shuaibu, (2011) the integration of trees in the agricultural landscape promotes diversification and sustainable production for increase social, economic and environmental benefits to all land users at all levels. However, the diversity of the
African tropical rainforests and the rich genetic pool they contain provide resources of vast potential that has been badly exploited with little or no regard for sustainability. The timber rich zones of Africa are faced with diminishing forest resources due to forest degradation, human and animal population increase, mismanagement of the forest and other forms of forest exploitation (Akinwale, 2017). Rural people have been discovered to have a wealth of indigenous knowledge and have incorporated trees in production systems in areas where they lived for a very long period of time (Evans and Alexander, 2004). These trees incorporated provide a lot of benefits to the land, crop planted and the environment (the ecosystem in general). The trees grown on different farmlands in the same locality can bring about improved wooded situation thereby enhancing environmental protection (Otegbeye, 2002). Given the reality of the importance of multiple land use management, the need to engage in the best agroforestry practices and adopt high yielding methods becomes necessary in the face of increasing population and limited nature of land. Agroforestry has both protective and socio-economic benefits (Anderson and Sinclair, 1993; Kang et al.,

*Corresponding AuthorEmail: obadolusola@gmail.com 
1990). Agroforestry systems is crucial to smallholder farmers and other rural people because it can enhance their food supply, income and health. This diversity in agroforestry practices call for the choice of appropriate methods that give the rural arable farmers the best results. Choosing appropriate agroforestry practices offer practical ways of applying various specialized knowledge and skills to the development of sustainable rural production systems.

In view of the above, this study profile the socioeconomic characteristics of the farmers, the major agroforestry practices and examine factors that determine the choice of agroforestry practice in Oyo state, Nigeria

The Study Area and Data Collection: The study was carried out in Oyo State. It shares international boundary with the Republic of Benin to the West, interstate boundaries with Osun State to the East, Kwara State to the North and Ogun State to the South. Approximately, it has a land area of $28,454 \mathrm{Km}^{2}$, with coordinates: Latittude $7^{\circ} 51^{\prime} \mathrm{N}, 9^{\circ} 25^{\prime} \mathrm{N}$ and Longitude $3^{\circ} 55^{\prime} \mathrm{E}, 52^{\circ} 50^{\prime} \mathrm{E}$. It has an estimated total population of 7,840,864 as at 2016 (NBS, 2017).

The primary data for this study were obtained through the use of a well-structured questionnaire using multistage sampling technique. Based on the existing Agricultural Development Programmes (ADP), the State was stratified into four (4) zones. Two (2) ADP zones were purposely selected based on the preponderance of agroforestry farmers. Each zone consists of five to eight blocks while each block represents a Local Government Area. A block is made up of eight cells, each cell represents a village. Two farmers were randomly selected from each village and a total of 250 questionnaire were distributed among the farmers while 211 only was utilized for this study.

Data Analysis: Descriptive Statistics such as frequencies and percentages were used to profile the socio-economic characteristics of the respondents while Multinomial Logit Model was used to investigate the determinants of choice of agroforestry practices adopted by the farmers.

The model is specified following the works of Ojo et al., (2013), Fasakin, (2012) and Rahji and Fakayode, (2009), let $\pi \mathrm{j}$ denote the multinomial probability of an observation falling in the $\mathrm{j}^{\text {th }}$ category, to find the relationship between this probability and the $\mathrm{p}$ explanatory variables, $\mathrm{X}_{1}, \mathrm{X}_{2},, \ldots \ldots \ldots . . . \mathrm{X}_{\mathrm{p}}$, the multiple logistic regression model is given thus: $\log \left[\frac{\pi_{j}\left(x_{i}\right)}{\pi_{k}\left(x_{i}\right)}\right]=a_{0 i}+\beta_{1 j} x_{1 i}+\beta_{2 j} x_{2 i}+\ldots .+\beta_{p j} x_{p i}$,

Where $\mathrm{j}=1,2 \ldots(\mathrm{k}-1), \mathrm{i}=1,2 \ldots \mathrm{p}$.

$\mathrm{K}=$ number of response or dependent category (Agrisilviculture, Silvopastoral and Agrosilvopastoral).

Note: one of the categories will be considered as the base outcome level and the multinominal logit will be constructed relative to it. $\mathrm{P}=$ number of explanatory variables included in the model.

In practice, when estimating the model, the coefficients of the reference group are normalized to zero (Greene 1993; Kimhi 1994; Rahji and Fakayode 2009, Ojo et al., 2013). This is because, the probabilities for all the choices must sum up to unity (Greene 1993). Hence, for 3 choices only (3 -1) distinct sets of parameters can be identified and estimated. The natural logarithms of the odd ratio of equations (1) and (2) give the estimating equation (Greene 1993) as:

$$
\left.\log \pi_{j}\left(x_{i}\right)\right)=\frac{\exp \left(a_{0 i}+\beta_{1 j} x_{1 i}+\beta_{2 j} x_{2 i}+\ldots .+\beta_{p j} x_{p i}\right)}{1+\sum_{j=1}^{k-1} \exp \left(a_{0 i}+\beta_{1 j} x_{1 i}+\beta_{2 j} x_{2 i}+\ldots . .+\beta_{p j} x_{p i}\right)}
$$

For $\mathrm{j}=1,2 \ldots(\mathrm{k}-1)$, the model parameters are estimated by the method of multinomial logit.

The independent variables include: $\mathrm{X}_{1}=$ Age (years), $X_{2}=\operatorname{Sex}($ male $=1$, if otherwise $=0), X_{3}=$ Household Size, $X_{4}=$ Farm /land size cultivated (hectare), $\mathrm{X}_{5}=$ Farming Experience (years), $\mathrm{X}_{6}=$ Education Level, $\mathrm{X}_{7}=$ Meeting attendance, $\mathrm{X}_{8}=$ Primary Occupation, $\mathrm{X}_{9}=$ Access to credit (Yes $=1$, otherwise $=0), X_{10}=$ Types of labour used, $X_{11}=$ Household Assets, $\mu=$ Error term.

\section{RESULTS AND DISCUSSION}

Table 1 shows the socio-economic characteristics of the respondents in the study area. It shows that $65 \%$ of the respondents were within the age range of 41 years, $61 \%$ were within the age range of 41-60years, while $7.6 \%$ were the ages of 60 above years. This implies that majority of the respondents were still in their active age as such could participate effectively in agroforestry activities. The findings also revealed that $19.9 \%$ of the respondents had no formal education, $17.5 \%$ had adult education, $21.3 \%$ had primary education, $61 \%$ had secondary education while $12.3 \%$ 
had tertiary education which implies that majority of the respondents had one form of formal education or the other. This result is in conformity with that of Iwala (2004) that education is related not only to the ability to obtain and process information, but also to the use of improved technology by the farmers. The study also revealed that $81.1 \%$ of the respondents were male while $10.9 \%$ were female indicating that men are mostly involved in the occupation because agroforestry farming requires a lot of energy. This result supports the earlier findings of Adereti and Fasina, (2017) that number of males involve in agroforestry practices usually exceed that of the females. It was also observed from the findings that $10.4 \%$ of the respondents were single, $87.2 \%$ were married while $2.4 \%$ were widow. Hence, the majority of the respondents were matured and responsible for their wellbeing. Furthermore, $36.5 \%$ of the respondents had $1-5$ household size, $56.4 \%$ had $6-10$ household size while $7.1 \%$ of the respondent had 1120 household size. This implies that the respondents' household sizes were moderate and could also be used as family labour. Also, about $1.8 \%$ of the respondents engaged in trading, $83.9 \%$ in farming and $10.3 \%$ in others as their primary occupation. The years of farming experience shows that $22.3 \%$ of the farmers had $1-5$ years farming experience, $45.5 \%$ had $6-10$ years of farming experience, and $27.5 \%$ had $11-15$ years while $5.2 \%$ had above 15 years of farming experience. Majority (55\%) of the respondents practiced agrisilviculture, $11 \%$ practiced silvopastoral while $33.2 \%$ practiced agrosilvopastoral form of agroforestry.

\begin{tabular}{|c|c|c|c|c|}
\hline Variables & $\begin{array}{l}\text { Group 1 } \\
\text { Agrisilvicutural }\end{array}$ & $\begin{array}{l}\text { Group 2 } \\
\text { Silvopastoral }\end{array}$ & $\begin{array}{l}\text { Group 3 } \\
\text { Agrosilvopastural }\end{array}$ & Total \\
\hline \multicolumn{5}{|l|}{ Age } \\
\hline$\leq 40$ & 36 & 9 & 20 & $65(30.0 \%)$ \\
\hline$\overline{4} 0-60$ & 72 & 15 & 43 & $130(61.6 \%)$ \\
\hline$>60$ & 8 & 1 & 7 & $16(7.6 \%)$ \\
\hline \multicolumn{5}{|l|}{ Gender } \\
\hline Male & 110 & 22 & 56 & $188(89.1 \%)$ \\
\hline Female & 6 & 3 & 14 & $23(10.9 \%)$ \\
\hline \multicolumn{5}{|l|}{ Marital Status } \\
\hline Single & 12 & 0 & 10 & $22(10.4 \%)$ \\
\hline Married & 102 & 25 & 57 & $184(87.2 \%)$ \\
\hline Widow & 2 & 0 & 3 & $5(2.4 \%)$ \\
\hline \multicolumn{5}{|l|}{ Pry Occupation } \\
\hline Block-maker & 2 & 0 & 0 & $2(0.9 \%)$ \\
\hline Civil servant & 9 & 3 & 4 & $16(7.4 \%)$ \\
\hline Farming & 95 & 22 & 60 & $177(83.9 \%)$ \\
\hline Medical Practitioner & 0 & 0 & 2 & $2(0.9 \%)$ \\
\hline N-Power & 0 & 0 & 2 & $2(0.9 \%)$ \\
\hline Teacher & 2 & 0 & 0 & $2(0.9 \%)$ \\
\hline Trading & 8 & 0 & 2 & $10(4.7 \%)$ \\
\hline \multicolumn{5}{|l|}{ Household } \\
\hline $1-5$ & 40 & 9 & 28 & $77(36.5 \%)$ \\
\hline $6-10$ & 71 & 16 & 32 & $119(56.4 \%)$ \\
\hline $11-15$ & 4 & 0 & 8 & $12(5.7 \%)$ \\
\hline $16-20$ & 1 & 0 & 2 & $3(1.4 \%)$ \\
\hline \multicolumn{5}{|l|}{ Education Status } \\
\hline No Education & 18 & 8 & 16 & $42(19.9 \%)$ \\
\hline Adult Education & 21 & 6 & 10 & $37(17.5 \%)$ \\
\hline Primary Education & 27 & 4 & 14 & $45(21.3 \%)$ \\
\hline Secondary Education & 33 & 6 & 22 & $61(28.9 \%)$ \\
\hline Tertiary Education & 17 & 1 & 8 & $26(12.3 \%)$ \\
\hline \multicolumn{5}{|l|}{ Farm size/Hectare } \\
\hline$<6$ ha & 95 & 20 & 61 & $176(83.4 \%)$ \\
\hline 6-10ha & 17 & 3 & 7 & $27(12.8 \%)$ \\
\hline$>10 \mathrm{ha}$ & 4 & 2 & 2 & $8(3.8 \%)$ \\
\hline \multicolumn{5}{|l|}{ Years of Experience } \\
\hline$<5$ yrs & 24 & 6 & 17 & $47(22.3 \%)$ \\
\hline $6-10 y r s$ & 52 & 10 & 34 & $96(45.5 \%)$ \\
\hline $11-15 y r s$ & 35 & 7 & 15 & $57(27.0 \%)$ \\
\hline$>15 \mathrm{yrs}$ & 5 & 2 & 4 & $11(5.2 \%)$ \\
\hline Total & $116(55 \%)$ & $25(11.8 \%)$ & $70(33.2 \%)$ & $211(100 \%)$ \\
\hline
\end{tabular}

Determinants of Agroforestry Practices: The multinomial logit analysis showing the factors that influence the choice of agroforestry practices adopted by the farmers is shown in Table 2 . The inference from 
the estimated coefficients for each choice category was made with reference to group 1(Agrisilviculture). The $\log$ likelihood ratio $(\chi 2)$ value was -186.01504 and this is significant at $5 \%$ level of probability. This test confirms that all the slope coefficients are significantly different from zero. The pseudo $\mathrm{R}^{2}$ value of 0.0855 also confirmed that all the slope coefficients are not equal to zero. Hence, the explanatory variables are collectively significant in explaining the choice of agroforestry practices by arable crop farmers in the study area. Evidence from the model shows that the set of significant explanatory variables varies across the groups in terms of the levels of significance and signs. From the analysis, the first regression in reference to silvopastoral practices, indicated that educational level was statistically significant at 5\% ( $>>0.05)$, with a negative coefficient. Though, the coefficients of gender, farming experience, meeting attendance, household assets and access to credit were positive but not significant. This finding contradict the findings of Akinwale, (2017) and Bifarin et al., (2013), where educational levels positively influence the adoption of agroforestry practices in Ondo state. This may not be unconnected with the fact that irrespective of their educational level, most farmers in the location are still not comfortable with the presence of trees on farmlands though they get involved in its planting. Domestic animals such as cattle sheep and goats are still allowed to graze and browse freely on the vegetation in the surrounding environment. The second outcome in reference to agrosilvopastoral practices indicated that gender $(p>0.10)$, meeting attendance $(p>0.05)$, types of labour used $(p>0.05)$ and household's assets $(p>0.01)$ were statistically significant with gender and types of labour used having negative coefficients, and meeting attendance and household's assets having positive coefficients respectively. The positive sign implies that the probability of choosing agrosilvopastoral practices tends to increase with increase regular meeting attendance and increase in possession of household assets. Farm size, age and primary occupation were not significant in the two outcomes and these agreed with the findings of Akinwale (2017) and Angba (2000). Meeting attendance is a form of social capital and positively influences the adoption of agroforestry practices in the study area. In the findings of Balogun et al., (2018) social capital positively affect the productivity of cassava farmers in Ogun State, Nigeria. Farmers who attend meetings regularly were better positioned to enjoy the benefits coming to the association.

Table 2: Determinants of preference for Agroforestry Practices in Oyo State, Nigeria

\begin{tabular}{|c|c|c|c|c|c|c|}
\hline Variable & Coef. & Std. Err & $\mathbf{P}>/ \mathbf{z} /$ & Coef. & Std. Err & $\mathbf{P}>/ \mathbf{z} /$ \\
\hline Age & -0.011 & 0.025 & 0.663 & 0.010 & 0.019 & 0.590 \\
\hline Gender & 0.289 & 0.477 & 0.544 & -0.574 & 0.331 & $0.083^{*}$ \\
\hline Household size & -0.032 & 0.125 & 0.795 & -0.055 & 0.091 & 0.547 \\
\hline Farm Size & -0.060 & 0.118 & 0.607 & -0.075 & 0.086 & 0.378 \\
\hline Farming experience & 0.061 & 0.043 & 0.153 & -0.013 & 0.036 & 0.728 \\
\hline Education level & -0.370 & 0.185 & $0.045^{* *}$ & -0.088 & 0.136 & 0.518 \\
\hline Meeting attendance & 0.244 & 0.460 & 0.596 & 0.930 & 0.357 & $0.009 * *$ \\
\hline Pry occupation & 0.466 & 0.483 & 0.334 & 0.025 & 0.339 & 0.942 \\
\hline Access to credit & 0.411 & 0.472 & 0.384 & 0.221 & 0.345 & 0.522 \\
\hline Type of labor & -0.023 & 0.317 & 0.941 & -0.463 & 0.226 & $0.040 * *$ \\
\hline Household asset & 0.126 & 0.112 & 0.261 & 0.293 & 0.085 & $0.001 * * *$ \\
\hline Constant & -2.025 & 1.719 & 0.239 & -1.085 & 1.277 & 0.395 \\
\hline No of Obs. & \multirow{3}{*}{\multicolumn{2}{|c|}{$\begin{array}{l}211 \\
-186.01504 \\
0.086\end{array}$}} & & Pro $>$ chi 2 & \multicolumn{2}{|l|}{$0.041 * *$} \\
\hline Log likelihood & & & & LR chi2 & 34.49 & \\
\hline Pseudo R-square & & & 0.086 & & & \\
\hline
\end{tabular}

Conclusion: Increased Meeting attendance and farmers household assets were the major determinant factors influencing the adoption of agroforestry practices among the farmers. Therefore, improved agroforestry techniques should be well communicated by extension workers to the farmers during meetings while provision of required infrastructural facilities should be prioritized by the government.

Acknowledgement: The authors acknowledge the contribution of Forestry Research Institute of Nigeria for the provision of enabling environment to successfully accomplish this work.

\section{REFERENCES}

Adereti, DT; Fasina, OO (2017). Gender analysis of food security status of rural households in Ondo State, Nigeria. Russian Agric. Sc. 43, 353-360

Akinwale, BO (2017). Determinants of Adoption of Agroforestry Practices among Farmers in Southwest Nigeria. Appl. Trop. Agric. A publication of the School of Agriculture and 
Agricultural Technology, The Federal University of Technology, Akure, Nigeria 22(2), 67-72.

Alao, JS; Shuaibu, RB (2011). Agroforestry Practices and Preferential Agroforestry Trees among farmers in Lafia Local Government Area, Nasarawa State, Nigeria. Waste Manage. and Biores. Tech. 1(2): 12-20.

Anderson, IS; Sinclair, FL (1993). Ecological Interactions in Agroforestry Systems. Agrofor. Sys. 6(2): 58-61.

Angba, AO (2000). Determinant of Sustained use of selected technologies recommended to farmers by Cross River State Agricultural Development Programme (ADP). Unpublished Ph.D Thesis. University of Ibadan, Nigeria

Balogun, OL; Ogunsina, IJ; Ayo-Bello, TA; Afodu, OJ (2018). Effect of Social Capital on Productivity of Cassava Farmers in Ogun State, Nigeria, J. of Agric. Sc. 63(1): 99-112

Bifarin, JO; Folayan, AJ; Omoniyi, LO (2013). Assessment of agroforestry practices as a land use option for sustainable agricultural Production in Osun State. Res. J. of Agric. and Environ. Mgt. 2(3): 69-74.

Evans, A; Alexander, I (2004). Organic Farming Supports Biodiversity in Farming with Nature, Low external Input and Sustainable agriculture Amersfoort, the Netherlands. p 36.

FAO (2015). Food and Agricultural Organization Online Statistical Database on Agroforestry practices, Rome, Italy: Food and Agriculture Organization of the United Nations. From $<$ http://www.fao.org/> (Retrieved on March, 2020).

Fasakin, IJ (2012). Adaptation of Cocoa Farmers to Climate Change in Ekiti State, Nigeria. https://www.researchgate.net/project/adaptationof-cocoa-farmer-to-changes-in-climaticconditions-in-Ekiti-state-Nigeria (Retrieved on March, 2020)
Greene, WH (1993). Econometric Analysis. London: Macmillan Publishing Company, pp 791.

Iwala, OS (2004). Socio-economic factors affecting the adoption of technological innovation by smallholder Oilpalm farmers in Edo and Ondo states of Nigeria, Unpublished Ph.D Thesis, Federal University of Technology Akure, Nigeria

Kang, BT; Reynolds, L; Atta-krah, AN (1990). Alley Farming advances in Agro-forestry. Agroforestry Sys. 43:315-359.

Kimhi, A. (1994). Participation of farm owners in farm and off-farm work including the option of fulltime off-farm work. J. of Agric. Econs., 45(2): 232-239.

NBS (2017). Demographic Statistics by National Bureau of Statistics, 2017.

Ojo, MA; Nmadu, JN; Tanko, L; Olaleye, RS (2013). Multinomial Logit Analysis of Factors Affecting the Choice of Enterprise among Small-holder Yam and Cassava Farmers in Niger State, Nigeria. J. of Agric. Sc. 4(1), 7-12.

Otegbeye, GO (2002). Report on Agroforestry and Land Management Practices, Diagnostics Survey of Katsina State of Nigeria. May 2000, Katsina State Agricultural and Rural Development Authority.Katsina. p 89.

Rahji, MAY; Fakayode, SA (2009). A Multinomial Logit analysis of Agricultural Credit Rationing by Commercial Banks in Nigeria. Int. Res. J. of Fin. and Econs. 24, 91

Udofia, SI (2005).Conservation of biodiversity through appropriate sustainable forest management strategies. Proceedings of 30th Annual Conference of Forestry Association of Nigeria held in Kaduna, 7th-11th November, 2005, p 92-104. 